\title{
COVID -19: INCESSANT LOCKDOWNS IMPACT ON TRIBAL COMMUNITY IN INDIA
}

\author{
${ }^{1}$ Prof.P.Manjushree, ${ }^{2}$ P.Geetha \\ ${ }^{I}$ Department of Entrepreneurship, GITAM Institute of Management, GITAM (Deemed to be University) \\ ${ }^{2}$ Research Scholar, Department of Entrepreneurship, GITAM Institute of Management, GITAM \\ (Deemed to be University)
}

Article DOI: $\underline{\text { https://doi.org/10.36713/epra7863 }}$

DOI No: 10.36713/epra7863

\begin{abstract}
It is a well-documented fact that COVID -19 pandemic is having a ravaging effect across the world, lives, livelihoods, lifestyles, life forms and more have been heavily impacted. To control the spread of pandemic Indian government adopted different approaches like - three weeks lockdown imposing social distancing, closure of non essential and businesses and very high restrictions on the mobility of people. All these measure had repercussions on the economy and severe impact among the tribal communities because of limited resources of livelihood, lack of access to Covid-19 testing and healthcare facilities, disruption of supply chains etc. According to government sources more than 10 crore forest dwellers depend on minor forest produce (MFPs) for earning income to meet their basic expenses. Due to the extensive lock down measures government failed to provide employment to tribal people under schemes like the Mahatma Gandhi National Rural Employment Guarantee Act (MGNREGA) and Pradhan Mantri Van Dhan Yojana (PMVDY). This has triggered an increase in the dependence of the tribal population on the sale of forest produce. Ministry of Tribal Affairs (MoTA) should plan more supportive policy measures to reduce the impact of the pandemic on the living conditions of the tribal community.The paper focusses on the first wave of the pandemic and its impact on tribal community.
\end{abstract}

KEY WORDS: COVID -19,lock down, tribal community, impact, minor forest produce(MFPS), ministry of tribal affairs (MoTA), Mahatma Gandhi National Rural Employment Guarantee Act (MGNREGA).

\section{INTRODUCTION}

It is a well-documented fact that COVID -19 pandemic is having a ravaging effect across the world, Lives, livelihoods, lifestyles, life forms and more have been heavily impacted. The broader business spectrum is bearing the brunt of the pandemic inflicted damage. To control the spread of pandemic Indian government adopted different approaches like - three weeks lockdown since March 25 ${ }^{\text {th }}, 2020$ to $14^{\text {th }}$ April 2020, imposing social distancing, closure of non essential and businesses and very high restrictions on the mobility of people. All these measure had repercussions on the economy and severe impact among the tribal communities because of limited resources of livelihood, lack of access to Covid-19 testing and healthcare facilities, returning of migrant workers, disruption of supply chains etc.The basic survival of tribal community was difficult during lock down due to lack of minor forest produce buyers and according to ministry of tribal affairs (MoTA) 20 to $40 \%$ of tribals depend on minor forest produce (MFP) for annual income. In 2011-12 Schedule Tribe (ST) people living below the poverty line in rural areas were $45.3 \%$ and $24.1 \%$ in the urban areas as compared to $25.7 \%$ in rural areas and $13.7 \%$ in urban areas for all population. Tribal women constitute 49 percent of total tribal population and the impact of pandemic was severe on tribal women because it is their economic back bone. The challenge for the government is to support the fragile tribal community by introducing special packages under ministry of tribal affairs (MoTA). With this background the study attempts to discuss the impact of Covid 19 on tribal community and businesses. The qualitative paper is organized under different sections starting with section I- review of literature, section II-tribal population in India, section III- Lock down Impact on tribal community, Section IV- Uncertain future, unpredictable markets and Paucity of government measures, section V - The government's helping hand and section VI -conclusion. 


\section{SECTION I : REVIEW OF LITERATURE}

According to Ministry of tribal Affairs (MoTA) tribals derive 20-40 per cent of their annual income from minor forest produce (MFP) and around 100 million forest dwellers depend on MFPs for food, shelter, medicines and cash income.

Indian Express (May,2020) reported widespread loss of livelihood and deepening economic distress among tribal communities across the country due to covid 19 lock down in March and April ,2020.

According to State of India's Poor: August 2020 In Focus: Tribal Community -The impact of covid 19 has been most disproportionately vulnerable among the tribal community due to their remoteness and lack of resources. Added to this they have been hit hard by the unplanned lockdown, with job losses, loss of wages, as well as difficulty in accessing relief.

M S Swaminathan Research Foundation report highlights that the national lockdown due to covid 19 from 25 March 2020 has severely affected lives and livelihoods across rural India. In addition to farm based activities Tribal communities were badly affected with no collection agents for collection and sale of nontimber forest produce.

International Labour Organization- COVID-19 and the world of work (2020) report analysis states that the impact of covid 19 on income-generating activities is especially harsh for unprotected workers and the most vulnerable groups in the informal economy.

Hoipi Haokip, Arfina Haokip, Tingneichong Gangte (2020) study states that COVID-19 affected the livelihood pattern of women market vendors in New Lambulane Tribal Market of Imphal East (Manipur) between 19 May and 30 June 2020.

Forests and forest resources, primarily minor forest products (MFP) or NWFPs(non-wood forest products), play an important role in the viability and survival of tribal households in Andhra Pradesh and elsewhere in India, because of the importance of forests in their social, cultural and economic survival (Tewari, 1989)

The primitive tribal economy is intimately connected with forests. Non-Timber Forest Products (NTFPs) form the main stay of income and sustenance for many of these tribal communities (Rao, 1987; Gauraha, 1992; Chopra, 1993; Mallik, 2000).

\section{SECTION II : TRIBAL POPULATION IN INDIA}

The scheduled Tribes (STs) population in the country as per 200 census is 10.45 crores. The Tribal population comprises of $8.6 \%$ of India's total population and around $11 \%$ of the total rural population. In India the total tribal population is around ten crore forty five lakhs in which nine crore forty lakh people live in rural areas and one crore four lakh sixty thousand tribal people live in urban areas. The population of ST male is 5.25 crore and females is 5.20 crore. The top states in India with highest ST population areLakshadweep 94.8\% Mizoram 94.4\% Nagaland $86.5 \%$ Meghalaya $86.1 \%$.Comparatively, the significant number of tribal population is in Madhya Pradesh with an average of $15 \%$ with reference to India's total Tribal Population, succeeded by Maharashtra with an average of $10 \%$ followed by Rajasthan, Gujarat\& Odisha with $9 \%$ of average and Jharkhand with $8 \%$ of total tribal population. States like Karnataka, West Bengal, Telangana, Andhra Pradesh and Assam further contribute to the total tribal population.The Male tribal population is $(50.26$ percent) followed by female tribal population (49.73 percent ) of the total population.

Table 1: State / UT wise Population of Scheduled Tribes by Sex and Residence: Census 2011

\begin{tabular}{|c|l|c|c|c|}
\hline S. No. & \multicolumn{1}{|c|}{ India / State / Uts } & Person & Male & Female \\
\hline & INDIA & $10,45,45,716$ & $5,25,47,215$ & $5,19,98,501$ \\
\hline 1 & JAMMU \& KASHMIR (UT) & $12,75,106$ & $6,66,062$ & $6,09,044$ \\
\hline 2 & LADAKH (UT) & $2,18,193$ & $1,10,195$ & $1,07,998$ \\
\hline 3 & HIMACHAL PRADESH & $3,92,126$ & $1,96,118$ & $1,96,008$ \\
\hline 4 & UTTARAKHAND & $2,91,903$ & $1,48,669$ & $1,43,234$ \\
\hline 5 & RAJASTHAN & $92,38,534$ & $47,42,943$ & $44,95,591$ \\
\hline 6 & UTTAR PRADESH & $11,34,273$ & $5,81,083$ & $5,53,190$ \\
\hline 7 & BIHAR & $13,36,573$ & $6,82,516$ & $6,54,057$ \\
\hline 8 & SIKKIM & $2,06,360$ & $1,05,261$ & $1,01,099$ \\
\hline 9 & ARUNACHAL PRADESH & $9,51,821$ & $4,68,390$ & $4,83,431$ \\
\hline 10 & NAGALAND & $17,10,973$ & $8,66,027$ & $8,44,946$ \\
\hline 11 & MANIPUR & $11,67,422$ & $5,88,279$ & $5,79,143$ \\
\hline 12 & MIZORAM & $10,36,115$ & $5,16,294$ & $5,19,821$ \\
\hline 13 & TRIPURA & $11,66,813$ & $5,88,327$ & $5,78,486$ \\
\hline 14 & MEGHALAYA & $25,55,861$ & $12,69,728$ & $12,86,133$ \\
\hline
\end{tabular}




\begin{tabular}{|l|l|c|c|c|}
15 & ASSAM & $38,84,371$ & $19,57,005$ & $19,27,366$ \\
\hline 16 & WEST BENGAL & $52,96,953$ & $26,49,974$ & $26,46,979$ \\
\hline 17 & JHARKHAND & $86,45,042$ & $43,15,407$ & $43,29,635$ \\
\hline 18 & ODISHA & $95,90,756$ & $47,27,732$ & $48,63,024$ \\
\hline 19 & CHHATTISGARH & $78,22,902$ & $38,73,191$ & $39,49,711$ \\
\hline 20 & MADHYA PRADESH & $1,53,16,784$ & $77,19,404$ & $75,97,380$ \\
\hline 21 & GUJARAT & $89,17,174$ & $45,01,389$ & $44,15,785$ \\
\hline 22 & DAMAN \& DIU & 15,363 & 7,771 & 7,592 \\
\hline 23 & DADRA \&NAGAR HAVELI & $1,78,564$ & 88,844 & 89,720 \\
\hline 24 & MAHARASHTRA & $1,05,10,213$ & $53,15,025$ & $51,95,188$ \\
\hline 25 & TELANGANA & $32,86,928$ & $16,59,963$ & $16,26,965$ \\
\hline 26 & ANDHRA PRADESH & $26,31,145$ & $13,09,399$ & $13,21,746$ \\
\hline 27 & KARNATAKA & $42,48,987$ & $21,34,754$ & $21,14,233$ \\
\hline 28 & GOA & $1,49,275$ & 72,948 & 76,327 \\
\hline 29 & LAKSHADWEEP & 61,120 & 30,515 & 30,605 \\
\hline 30 & KERALA & $4,84,839$ & $2,38,203$ & $2,46,636$ \\
\hline 31 & TAMIL NADU & $7,94,697$ & $4,01,068$ & $3,93,629$ \\
\hline 32 & ANDAMAN \& NICOBAR & 28,530 & 14,731 & 13,799 \\
\hline & ISLANDS & & & \\
\hline
\end{tabular}

Note: No Notified Scheduled Tribes in Punjab, Chandigarh, Haryana, NCT of Delhi and Puducherry as in 2011. Source: Ministry of Tribal Affairs-Annual Report -2019-20

\section{SECTION III : LOCK DOWN IMPACT ON TRIBAL COMMUNITY}

As per Ministry of tribal Affairs (MoTA) estimates the livelihood of at least $25 \mathrm{crore}$ rural/tribal is through business, generated from forest products. The lockdown and resultant lack of business has had a crippling effect on majority of the tribal community because they depend on forest produce for livelihood.

For example, the forest products retailing sector engages a large number of tribal; each one of them makes about Rs 25000 every year between March and July which is the peak season by collecting and selling Mahuwa, Karanjseed, cashew, Tamarind and other forest products in the market. But this year the picture is radically different. The income which the tribal community typically earn during this period has come down crashing by $70 \%$ approximately. Lockdown and lack of buyers has caused this cascading effect. The Corona unleashed lockdown has undoubtedly impacted the indigenous economy dependent predominantly on minor forest products retail. The situation has not witnessed any significant improvement after the lockdown related relaxations.

\section{SECTION IV : UNCERTAIN FUTURE, UNPREDICTABLE MARKETS AND PAUCITY OF GOVERNMENT MEASURES}

It is assumed that annually the tribal people manage to collect about Rs 2 Lakh crore worth of nontimber forest products (NTFP) from across the country's forest ecosystem. But all that is going to change for the bad this year. The lockdown relaxation doesn't hold good for traders and contractors who purchase the forest products from tribal community because they are dependent on vehicles to transport the purchased produce. NTFPs and MFPs (Minor Forest Products) plays a significant role in the economic model of the tribal communities. According to government sources more than 10 crore forest dwellers depend on MFPs for earning income to meet their basic expenses. Across India, there are around 200 authorized minor forest products which include products like Tendu leaf or east Indian ebony, Bamboo, Mahuwa or butternut flower and seed, Sal or Shorea leaf and seed, Lac, Chironjee (Cuddapah almond), Tamarind, gtree gum, and Karanj seed. According to Tribal Co-operative Marketing Development Federation (TRIFED), the cumulative value of just about 50 forest products is around a whopping Rs 20,000 Crores. All these numbers now stand radically altered as all the products of tribals are by default natural and the minimum support price can be increased as these products have high demand in the urban markets.

\section{Paucity of handholding measures}

Due to the extensive lock down measures government failed to provide employment to tribal people under schemes like the Mahatma Gandhi National Rural Employment Guarantee Act (MGNREGA) and Pradhan Mantri Van Dhan Yojana (PMVDY). This has triggered an increase in the dependence of the tribal population on the sale of forest produce. Post lockdown relaxation, the collection and purchase of MFPs has picked up. Yet it can easily be 
inferred that the lockdown has had an adverse impact on the larger tribal economy. In yet another flip side, most tribals are selling their produce at dirt cheap prices due to theabsence of buyers. This in turn is giving rise to exploitation by unscrupulous middlemen. The problem is all the more severe in remote areas set amidst inhospitable terrains. A classic case in point is the collection and sale of Mahuwa in these circumstances. The minimum assured rate by government for Mahuwa is Rs 25 per kilogram. But it is no longer sold at that cost as there is no market and no buyers.. And in the case of villages located in deep jungles barter is the only option. If this trend continues, the tribal economy is going to bleed profusely.

\section{Dysfunctional State Sponsored Support Networks}

The lock down measures to contain the pandemic aggravated the normal living conditions of tribal community because of two important reasons. Firstly the primary procurement agencies (PPAs) mooted by Tribal Cooperative Marketing Development Federation of India (TRIFED) for the implementation of MSP schemes are yet to be constituted or are nonfunctional and secondly due to poor accessibility to the public distribution system (PDS). Critical institutional support doesn't exist for collection and procurement of the MFPs assuring quick realization of payments. In 2019 Van Dhan Kendras were established under the scheme initiated by TRIFED, Ministry of Tribal Affairs to ensure that van dhan (forest wealth) stays in the hands of forest dwellers which will provide regular livelihood and income generation opportunities to tribal families. Kendras act as common facility centres in procurement and value addition of minor forestproduce (MFP) that are collected by tribals from the forest and to provide training relating to value addition, packaging, marketing \& branding activities through a cluster based approach. During the pandemic lock down period van dhan kendras in few states have been a life saver for tribals to process and sell their collected produce within their own villages.

The other state support measures like doorstep supply of ration, vegetables, and other essentials and implementation of Mahatma Gandhi National Rural Employment Guarantee Act (MGNREGA) scheme were not effectively implemented in tribal dominated areas.

Table 2 : State - wise status of establishment of Van Dhan Vikas Kendras-2018

\begin{tabular}{|c|c|c|c|c|c|}
\hline S.No & States & $\begin{array}{c}\text { No. of VDVKs } \\
\text { Sanctioned }\end{array}$ & $\begin{array}{c}\text { Fund } \\
\text { approved/ } \\
\text { sanctioned } \\
\text { (Rs. in Lakh) }\end{array}$ & $\begin{array}{c}\text { Fund } \\
\text { transferred } \\
\text { (Rs. in Lakh) }\end{array}$ & $\begin{array}{c}\text { Number of } \\
\text { Beneficiaries }\end{array}$ \\
\hline 1 & Goa & 1 & 15 & 0 & 300 \\
\hline 2 & Uttar Pradesh & 5 & 59.55 & 59.55 & 1238 \\
\hline 3 & Bihar & 8 & 81.5 & 0 & 1630 \\
\hline 4 & Tamil Nadu & 7 & 105 & 105 & 2100 \\
\hline 5 & Tripura & 9 & 121.9 & 121.9 & 2443 \\
\hline 6 & Kerala & 13 & 195 & 0 & 3900 \\
\hline 7 & Assam & 16 & 240 & 240 & 4974 \\
\hline 8 & Gujarat & 17 & 254.45 & 0 & 5087 \\
\hline 9 & Karnataka & 19 & 285 & 285 & 5700 \\
\hline 10 & Madhya Pradesh & 20 & 300 & 0 & 6000 \\
\hline 11 & Rajasthan & 25 & 372.2 & 372.2 & 7580 \\
\hline 12 & Andhra Pradesh & 30 & 450 & 450 & 9000 \\
\hline 13 & Nagaland & 31 & 465 & 465 & 9300 \\
\hline 14 & Jharkhand & 39 & 569.7 & 569.7 & 11601 \\
\hline 15 & Maharashtra & 64 & 960 & 960 & 19350 \\
\hline 16 & Manipur & 77 & 1155 & 1155 & 23259 \\
\hline 17 & Chhattisgarh & 139 & 2085 & 2085 & 41700 \\
\hline 18 & Odisha & 156 & 2269.25 & 2269.25 & 45578 \\
\hline & Total & 676 & 9983.55 & 9137.6 & 200740 \\
\hline
\end{tabular}


As per the ministry of tribal affairs annual report the total number of sanctioned Van Dhan Kendras are 676. Significant number of VDVK's were sanctioned for Odisha (156) followed by Chhattisgarh(139) Manipur (77) and Maharashtra (64) contributing to $64.5 \%$ of the total VDVK's sanctions. $91.5 \%$ of the sanctioned funds were transferred against the sanctioned amount.

The percentage of beneficiaries from Madhya Pradesh, Rajasthan, Andhra Pradesh, Nagaland, Jharkhand, Maharashtra, Manipur, Chhattisgarh and Odisha from Van Dhan Vikas Kendras were of $86 \%$ of total beneficiaries. Effective implementation of Van Dhan Kendras scheme in tribal dominated states will be an important milestone in the economic development of tribal population involved in MFP collection. Therefore, it becomes necessary to allocate adequate funds from Central government sponsored projects and State Plan schemes for the socioeconomic development of tribes particularly during the present pandemic time.

\section{SECTION V : THE GOVERNMENT'S HELPING HAND}

Responding to the crisis faced by the tribal communities, the union government has formulated a livelihood programme aimed at tribal populace. As per the estimate by the ministry of tribal affairs, around 20 Lakh tribal work in different parts of the country. Circumstances are forcing most of these people to depend on quarantine camps in their respective states. The ministry has framed an initiative called Livelihood with Safety. It includes commissioning 'tribal startups', which will encourage tribal to form self-help groups for revenue generation. The ministry has directed the states, especially those with high tribal population, to send in proposals for grants. Tribal Cooperative Marketing Development Federation of India (TRIFED) is engaged in framing specific programs for the states. The whole exercise is a platform to provide opportunities to tribal entrepreneurs and workers. Organizing small self-help groups and aggressively marketing the products is a core focus area.

Ministry of Tribal Affairs is the nodal Ministry for overall policy, planning and coordination of programmes/schemes for the development of schedule tribes. Ministry should plan specific and targeted measures including cash transfers ,alternative income generation activities for tribal community to avoid the risk of falling deeper into poverty during and after the crisis period.

To protect and support tribal community Tribal Cooperative Marketing Development Federation of India (TRIFED) sent proposals to MoTA for procurement of minor forest produces through van dhan centres
Forest rights' groups demanded the Ministry of Tribal Affairs to constitute a COVID Response Cell for tribal communities; to ensure and issue necessary guidelines or advisories to the states on measures to be taken for tribals and forest dwellers to deal with COVID-19 and the lockdown.

Support to tribal women entrepreneurs from state and central governments are implemented and women are encouraged to manufacture masks as part of Standup India and Pradhan Mantri Mudra Yojna (PMMY) schemes aimed at SMSEs including tribal women entrepreneurs -

The Covid19 pandemic should be a wake-up call for the government to rethink and redesign health, livelihood and food security measures for tribal communities that are sustainable and beneficial to the tribal community across the country. Covid 19 is an opportunity for governments to provide these essential workers with measures that always should have existed and that should be kept in place after the crisis subsides. (Harvey 2020)

Respective state governments should appoint local committees by including active tribal members to study the problems of tribal community because they are more likely to know what the local problems are also what the local tribal communities'value and implement the support measures as per the requirement.

Appropriate policy measures by the government will help the tribal community to regain their livelihoods during the post lock down period. Since majority of the tribal population depend on MFP government should concentrate on value addition facility for MFP by following public private partnership (PPP) model. In the PPP model government support is required for creating necessary infrastructure facilities and corporate sector support for processing and marketing of the produce.

\section{SUPPORT THROUGH TRIBAL SUB PLAN}

Government can support tribal community through special package in tribal sub plan scheme which is already implemented in many states so that many in tribal community will be benefited .Government of India has planned a separate tribal sub plans to help and protect the tribal community to overcome poverty and unemployment. Ministry of tribal affairs allocates funds to Tribal Sub Plan (TSPs) for various states in annual budget.For the development of schedule tribe population Tribal Sub Plan (TSP) now called Scheduled TribeComponent (STC) Strategy was adopted in 5th Five Year Plan (1974- 75). Under Special Central Assistance to Tribal Sub-Scheme (SCA to TSS) $100 \%$ grant is provided from GOI (since 197778). TSP funds are dedicated source of fund for tribal 
development. Ministry of Tribal Affairs provides additive to these initiatives by way of plugging gaps. The results of TSP / STC strategy have brought out some improvements relating to literacy, health, livelihood, etc. According to existing population more funds were released to Maharashtra, Rajasthan and Chhattisgarh. However, still gap exists in human development indices between Scheduled Tribes and other social groups.

Table 3 : Details of TSP funds Allocation to different State Governments under State Tribal Sub - Plan from 2017-18 to2019-20 (Rs. inCrores)

\begin{tabular}{|c|c|c|c|c|c|}
\hline S. No. & State/UT & 2017-18 & 2018-19 & 2019-20* & $\begin{array}{c}\text { Rank } \\
\text { Based on 2018- } \\
19 \\
\end{array}$ \\
\hline 1 & Arunachal Pradesh & - & 2211.83 & 3009.3 & 17 \\
\hline 2 & Andhra Pradesh & 3624.77 & 5617.39 & 7844.75 & 6 \\
\hline 3 & Assam & 0 & 0 & 2710.08 & 0 \\
\hline 4 & Bihar & 0 & 0 & 0 & 0 \\
\hline 5 & Chhattisgarh & 14327.57 & 10342.65 & 9055.53 & 5 \\
\hline 6 & Goa & 559.09 & 352.31 & 0 & 21 \\
\hline 7 & Gujarat & 10270.41 & 11765.38 & 8975.55 & 4 \\
\hline 8 & Himachal Pradesh & 2291.2 & 3628 & 1859.95 & 13 \\
\hline 9 & Jammu \& Kashmir & 3626.5 & 3749.8 & 4509 & 12 \\
\hline 10 & Jharkhand & 11372.49 & 8564.52 & 2674.22 & 7 \\
\hline 11 & Karnataka & 5955.37 & 5347.76 & 3768.5 & 23 \\
\hline 12 & Kerala & 808.43 & 335 & 0 & 22 \\
\hline 13 & Madhya Pradesh & 22828.7 & 16968.97 & 8841.16 & 2 \\
\hline 14 & Maharashtra & 13760.38 & 13802.57 & 11529.09 & 3 \\
\hline 15 & Manipur & 3790.38 & 5442.48 & 0 & 10 \\
\hline 16 & Meghalaya & - & 2739.2 & 2700 & 16 \\
\hline 17 & Mizoram & - & 1220 & 1683.75 & 19 \\
\hline 18 & Nagaland & - & 3225 & 1888 & 14 \\
\hline 19 & Odisha & 11975 & 17553.22 & 3394.39 & 1 \\
\hline 20 & Rajasthan & 10051.83 & 10327.93 & 9450 & 6 \\
\hline 21 & Sikkim & 5986 & 0 & 0 & 22 \\
\hline 22 & Tamil Nadu & 894.1 & 315 & 450.56 & 21 \\
\hline 23 & Telangana & 4493.55 & 2850.32 & 4022.38 & 15 \\
\hline 24 & Tripura & 1649.77 & 1294.38 & 1362.97 & 18 \\
\hline 25 & Uttarakhand & 679 & 1012.88 & 600 & 20 \\
\hline 26 & Uttar Pradesh & 458.35 & 0 & 0 & 0 \\
\hline 27 & West Bengal & 5397.11 & 5833.41 & 5122.58 & 8 \\
\hline & Total & 134800 & 134500 & 95451.76 & \\
\hline
\end{tabular}

Source : Annual Report -Ministry of Tribal Affairs 2019-20 2019-20* - Provisional Figures

Highest TSP funds were allotted to Odisha (Rs .17553.22) state during 2018-19 followed by Madhya Pradesh (Rs. 16968.97), Maharashtra (Rs.13802.57), Gujarat (Rs.11765.38) and Chhattisgarh(10342.65).These five states were allotted 52.36 percentage of TSP funds under state tribal sub plan. Ranking based on the TSP fuds allocation to different state governments during $2018-19$ is presented in table 3 .

\section{SECTION VI : CONCLUSION}

Lock down measures implemented by the government to control Covid 19 had repercussions on the economy and severe impact among the tribal communities because of limited resources of livelihood, lack of access to Covid-19 testing and healthcare facilities, returning of migrant workers, disruption of supply chains etc. As Ministry of Tribal Affairs is the nodal Ministry for overall policy, planning and coordination of programmes for development of STs as nodal ministry more support measures are to be planned to reduce the impact of the pandemic on the living conditions of the tribal community.

It is assumed that annually the tribal people manage to collect about Rs 2 Lakh crore worth of non- 
timber forest products (NTFP) from across the country's forest ecosystem. The lockdown and resultant lack of business has had a crippling effect on majority of the tribal community because they depend on forest produce for livelihood. The problems of trial community increased because the primary procurement agencies (PPAs) mooted by Tribal Cooperative Marketing Development Federation of India (TRIFED) for the implementation of MSP schemes are yet to be constituted or are nonfunctional and due to poor accessibility to the public distribution system (PDS).

Many reports suggested that government should implement relief measures with good packages $s$ to help the tribal community. Forest rights' groups demanded the Ministry of Tribal Affairs to constitute a COVID Response Cell for tribal communities; to ensure and issue necessary guidelines or advisories to the states on measures to be taken for tribes and forest dwellers to deal with COVID-19 and the lockdown. Respective state governments should appoint local tribal committees by involving local tribal members to study the problems because they are more likely to know what the local problems are and what the local tribal communities value so that swift policy measures can be implemented as per the requirement.

\section{REFERENCES}

1. Chopra, K., 1993, "The Value of Non-Timber Forest Products: An Estimation for Tropical Deciduous Forests in India", Economic Botany, Vol. 47, pp.251-257.

2. Gauraha, A.K., 1992, "Micro-Economic Analysis of a Tribal Village", Indian Journal of Agricultural Economics, 47(3): 446-447.

3. Hoipi Haokip, Arfina Haokip, Tingneichong GangteNegotiating Livelihood during COVID-19

4. Urban Tribal Women Vendors of Manipur,Economic and political weekly,Vol. 55, Issue No. 46, 21 Nov, 2020 . Mallik, R.H., 2000, "Sustainable Management of Non-Timber Forest Products in Orissa: Some Issues andOptions", Indian Journal of Agricultural Economics, 55(3): 384-397.

5. Ministry of tribal affairs, Annual Report,201819.https://www.scribd.com/document/444780551/a nnual-report-of-tribal-affairs-2018-19-pdf .Accessed on 30th,Oct,2020.

6. Oomen MA (2020)-COVID-19 in the Indian Context and the Quest for Alternative ParadigmsVol 55,Issue No.45,07,Nov,2020

7. https://tribal.nic.in/writereaddata/AnnualReport/AR English1920.pdf accessed on 30th,Oct,2020.

8. https://www.researchgate.net/publication/30879428 8_Tribes_and_Forest_A_critical_appraisal_of_th e_tribal_forest_right_in_India [accessed Nov 25 2020].

9. https://www.iwgia.org/en/news-alerts/news-covid19/3549-covid-19-india-reverse-migration.html

10. https://pib.gov.in/newsite/PrintRelease.aspx? relid= 178469
11. https://www.mssrf.org/content/impact-covid-19rural-lives-and-livelihoods-india- Accessed on 20th,Nov, 2020

12. https://www.censusindia.gov.in/2011census/hlo/SC _ST/St_data.html

13. https://www.ilo.org/wcmsp5/groups/public/--dgreports/-dcomm/documents/briefingnote/wcms_740877.pdf

14. https://www.financialexpress.com/industry/sme/ms me-exim-govt-reaches-out-to-women-led-msmesstartups-to-help-covid-hit-women-workers-earnlivelihood/1934554/

15. https://d3971b67-4c49-4f6d-aa7c63f2a5b3cac5.filesusr.com/ugd/8a8dda_faae03c27 307427b9f139258661af854.pdf.

16. https://www.tribal.nic.in/downloads/annualreport/AREnglish1920.pdf.Accessed on2nd,Nov, 2020.

17. The New Indian Express, 31 March,2020Coronavirus lockdown: Fear looms large over tribalcommunities, 2020, https://www.newindianexpress.com/nation/2020/ma r/31/coronavirus-fear-looms-large-over-tribalcommunities-2123864.html

18. The Economic Times, 1 April 2020 - Centre to ensure tribals get MSP for produce, https:/leconomictimes.indiatimes.com/news/econom y/agriculture/centre-to-ensure-tribals-get-msp-forproduce/printarticle/74923736.cms. 